\title{
Efektivitas Pemanenan Mikroalga (Spirulina platensis) dengan Metode Elektrokoagulasi menggunakan Tegangan yang Berbeda
}

\author{
The effectiveness harvesting of microalgae (Spirulina platensis) with \\ electrocoagulation method using different voltage
}

\author{
Aidil Fadli Ilhamdy ${ }^{1}$, Ginanjar Pratama ${ }^{2 *}$, Jumsurizal' ${ }^{1}$, Raja Marwita Sari \\ Putri $^{1}$, Darma Saputra ${ }^{1}$
${ }^{1}$ Jurusan Teknologi Hasil Perikanan, Fakultas Ilmu Kelautan dan Perikanan, Universitas Maritim Raja Ali Haji, Tanjungpinang, 29111, Indonesia
${ }^{2}$ Jurusan Perikanan, Fakultas Pertanian, Universitas Sultan Ageng Tirtayasa, Serang, 42122, Indonesia
*Korespondensi: ginanjarpratama@untirta.ac.id

\begin{abstract}
ABSTRAK
Penelitian budidaya Spirulina platensis skala laboratorium di Indonesia mengalami perkembangan yang cukup signifikan, tetapi banyak kendala pada saat pemanenan yaitu mulai dari harga yang tinggi, cara pemanenan yang kurang efektif dan waktu pemanenan yang sangat lama. Oleh karena itu penelitian ini bertujuan untuk mengetahui efektivitas penggunaan metode elektrokoagulasi dalam pemanenan $S$. platensis menggunakan tegangan yang berbeda. Tahapan penelitian meliputi budidaya mikroalga, proses elektrokoagulasi, dan pemanenan $S$. platensis, kemudian dilanjutkan dengan analisis biomassa $S$. platensis, komposisi proksimat, dan kualitas air $(\mathrm{pH}$, suhu, dan kadar besi $(\mathrm{Fe})$ ). Perlakuan panen mikroalga dengan metode elektrokoagulasi menggunakan tegangan $0,5,10$ dan 15 volt (kode masing-masing F0, F1, F2, dan F3). Panen biomassa terbaik dengan elektrokoagulasi dari perlakuan F3 adalah 6,05 gr/L. Hasil analisis proksimat $S$. platensis pada perlakuan F0, F1, F2, dan F3 berturut-turut yaitu kadar air sebesar 24,58\%; 12,32\%; 15,36\%; 17,48\%, kadar abu sebesar 26,56\%; 22,42\%; 26,53\%; $34,99 \%$, kadar protein sebesar 34,24\%; 30,26\%; 25,81\%; 21,67\%, kadar lemak sebesar $1,27 \% ; 0,86 \% ; 1,65 \% ; 0,65 \%$, dan kadar karbohidrat sebesar $13,35 \% ; 34,15 \% ; 30,66 \%$; $25,22 \%$. Hasil kualitas air perlakuan F0, F1, F2, dan F3 berturut-turut adalah pH 7, 7, 9, 8 , suhu $32^{\circ} \mathrm{C}, 32^{\circ} \mathrm{C}, 32^{\circ} \mathrm{C}, 34^{\circ} \mathrm{C}$, kadar besi (Fe) $0,1 \mathrm{mg} / \mathrm{L} ; 8,01 \mathrm{mg} / \mathrm{L} ; 12,58 \mathrm{mg} / \mathrm{L} ; 12,29$ $\mathrm{mg} / \mathrm{L}$. Perlakuan terbaik terjadi pada pemanenan F3 karena biomassa yang dipanen sangat tinggi.
\end{abstract}

Kata kunci: elektrokoagulasi; metode pemanenan; Spirulina platensis

\begin{abstract}
Research on laboratory scale Spirulina platensis cultivation in Indonesia has developed quite a lot, however, several obstacles occur at harvest time, ranging from high prices and a very long time. Therefore this study aims to determine the effectiveness of the use of electrocoagulation in harvesting S. platensis using different voltage. The research phase included microalgae cultivation, electrocoagulation process, and harvesting of $S$. platensis, then continued with an analysis of biomass $S$. platensis, proximate composition, and water quality ( $\mathrm{pH}$, temperature, and Ferro ( $\mathrm{Fe}$ ) content). The treatment of electrocoagulation method harvesting of microalgae with voltages $0,5,10$, and 15 volts (F0, F1, F2, and F3, respectively) were applied in this study. The best biomass harvested with electrocoagulation from F3 treatment was $6.05 \mathrm{gr} / \mathrm{L}$. The proximate content of $S$. platensis with F0, F1, F2, and F3 treatments were moisture $24.58 \%, 12.32 \%, 15.36 \%, 17.8 \%$, ash $26.56 \%, 22.42 \%, 26.53 \%, 34.99 \%$, protein
\end{abstract}


$34.24 \%, 30.26 \%, 25.81 \%, 21.67 \%$, fat $1.27 \%, 0.86 \%, 1.65 \%, 0.65 \%$, and carbohydrate $13.35 \%, 34.15 \%, 30.66 \%, 25.22 \%$, respectively. The water quality result showed with, $\mathrm{F} 0, \mathrm{~F} 1, \mathrm{~F} 2$, and $\mathrm{F} 3$ treatments were $\mathrm{pH} 7,7,9,8$, temperature $32^{\circ} \mathrm{C}, 32^{\circ} \mathrm{C}, 32^{\circ} \mathrm{C}, 34^{\circ} \mathrm{C}$, Ferro $(\mathrm{Fe}) \quad 0.1 \mathrm{mg} / \mathrm{L}, 8.01 \mathrm{mg} / \mathrm{L}, 12.58 \mathrm{mg} / \mathrm{L}, 12.29 \mathrm{mg} / \mathrm{L}$, respectively. The best treatment with electrocoagulation method harvesting was F3.

Keywords: electrocoagulation; harvesting method; Spirulina platensis

\section{PENDAHULUAN}

Mikroalga merupakan tumbuhan air tingkat rendah dengan ukuran mikroskopis (yang tidak dapat dibedakan berdasarkan akar, batang, dan daunnya). Mikroalga dapat tumbuh di daerah air tawar, payau, dan laut (Gami et al. 2011; Pohl et al. 1987; Puspanadan et al. 2018; Samek et al. 2013). Terdapat beberapa jenis kandungan dari mikroalga yang sangat bermanfaat bagi manusia, seperti xanthophyll, lutein, $\beta$-carotene, vitamin $\mathrm{C}$, vitamin $\mathrm{E}$, asam linoleat (LA), $\gamma$ linoleic acid (GLA), arachidonic acid (AA), eicosapentaenoic acid (EPA), dan docosahexaenoic acid (DHA) (Ambrozova et al. 2014; Spolaore et al. 2006; Zhu et al. 2018). Mikroalga memiliki polisakarida yang dapat diaplikasikan pada kosmetik, makanan fungsional, zat aditif makanan, dan bioremediasi (Spolaore et al. 2006). Spirulina platensis merupakan mikroalga yang banyak dibudidayakan di Indonesia karena mikroalga ini memiliki keunikan. Salah satu ciri khasnya adalah kandungan nutrisinya yang lengkap terutama protein mencapai 60-71\% (Hadiyanto dan Hendroko 2014). Kandungan tersebut mudah diserap dan dicerna oleh tubuh manusia karena memiliki dinding sel yang lunak (Promya et al. 2008).

Banyak penelitian budidaya $S$. platensis yang telah dilakukan dalam skala laboratorium karena tingginya permintaan terhadap $S$. platensis di pasaran (Soni et al. 2017). Kendati demikian, tantangan dan kendala yang dihadapi dalam penerapan skala usaha adalah teknologi pemanenannya. Menurut Sim et al. (1988), untuk menghasilkan biomassa yang lebih tinggi, teknik pemanenan memainkan peran penting dalam budidaya. Beberapa cara pemanenan dalam budidaya $S$. platensis adalah skrining, getaran ultrasonik, flotasi, flokulasi, sedimentasi, filtrasi, dan sentrifugasi (Barros et al. 2015; Sim et al. 1988; Singh dan Patidar 2018).

Chen et al. (2011) menyatakan bahwa pemisahan mikroalga dari media cair secara efektif dapat dilakukan menggunakan sentrifugasi kecepatan tinggi, meskipun dalam skala laboratorium proses ini efektif digunakan, namun proses ini juga memiliki kekurangan dalam hal biaya operasional. Menurut Grima et al. (2003), proses pemanenan mikroalga dengan ukuran sel yang besar paling efektif diterapkan menggunakan metode filtrasi. Namun, proses filtrasi belum sesuai untuk pemanenan mikroalga dengan ukuran sel yang kecil, dan pada metode ini waktu pemanenan yang dibutuhkan lebih lama.

Salah satu cara pemanenan mikroalga yang cepat dan praktis adalah dengan elektrokoagulasi (Ghernaout 2019). Menurut Mollah et al. (2001), elektrokoagulasi adalah proses pengendapan dan penggumpalan partikel halus dalam air, menggunakan energi listrik. Penelitian tentang elektrokoagulasi untuk pemanenan mikroalga jenis $S$. platensis masih dalam tahap pengembangan (Milledge dan Heaven 2013). Oleh karena itu, penelitian ini bertujuan untuk mengetahui efektivitas penggunaan elektrokoagulasi dalam pemanenan $S$. platensis menggunakan tegangan yang berbeda.

\section{METODE PENELITIAN}

Sampel S. platensis berasal dari Balai Besar Pengembangan Budidaya Air Payau (BBPBAP), Jepara, yang di 
kultivasikan di Laboratorium Kimia Fakultas Ilmu Kelautan dan Perikanan Universitas Maritim Raja Ali Haji untuk dilakukan pengujian lebih lanjut.

\section{Bahan}

Bahan utama yang digunakan adalah S. platensis. Bahan lain yang digunakan adalah akuades, alkohol (Merck, 99\%), $\mathrm{NaNO}_{3}$ (Merck, 99\%), $\mathrm{NaH}_{2} \mathrm{PO}_{4}$ (Merck, 99\%), $\mathrm{Na}_{2}$ EDTA (Merck, 99\%), $\mathrm{H}_{3} \mathrm{BO}_{3}$ (Merck, 99\%), $\mathrm{MnCl} 2$ (Merck, 99\%), $\mathrm{FeCl}_{3}$ (Merck, 99\%), vitamin $\mathrm{B}_{12}$ (IPI, 72\%), klorin (Merck, 99\%) dan natrium (Merck, $99 \%)$.

\section{Alat}

Alat-alat yang digunakan meliputi multitester (Lutron YK 2005 WA), Atomic Absorption Spectrophotometer (AAS) (Shimadzu AA-7000), spektrofotometer UV-Vis (Shimadzu UV 1800), oven (Memmert UN55), soxhlet (IWAKI Soxh Set 1000), Kjeldahl analisis (KjelFlex K-360) dan tanur (Thermolyne F6010),

\section{Proses Kultivasi (Ilhamdy et al. 2017)}

Sebanyak $2 \mathrm{ml}$ isolat $S$. platensis diinokulasi ke dalam 3 liter media Walne (100 $\mathrm{g} \mathrm{NaNO}_{3} ; 20 \mathrm{~g} \mathrm{NaH}_{2} \mathrm{PO}_{4} ; 45 \mathrm{~g}$ $\mathrm{Na}_{2}$ EDTA; 33,6 $\mathrm{g} \mathrm{H}_{3} \mathrm{BO}_{3} ; 0,36 \mathrm{~g} \mathrm{MnCl}_{2}$; $1,3 \mathrm{~g} \mathrm{FeCl}_{3}$ ). Selanjutnya proses inkubasi dilakukan selama seminggu. Pada proses ini inokulan yang telah dibudidayakan dipindahkan sebanyak $3 \mathrm{~L}$ ke dalam $30 \mathrm{~L}$ media Walne. Budidaya dilakukan pada wadah dengan aerasi nonstop di bawah sinar lampu dan ditempatkan pada suhu kamar. Pada proses ini dilakukan pengumpulan data pertumbuhan mikroalga setiap 24 jam yang meliputi Optical Density (OD), pH, dan suhu. Produktivitas biomassa diukur menggunakan spektrofotometer UV-Vis dengan panjang gelombang $620 \mathrm{~nm}$ berdasarkan densitas optiknya (OD) selama periode pertumbuhan. Mikroalga yang telah mencapai ukuran OD 0,5 (fase stationer) kemudian dipanen (Addini et al. 2017).

\section{Proses Elektrokoagulasi (Modifikasi Uduman et al. 2011)}

Pertumbuhan mikroalga yang telah mencapai ukuran OD 0,5 (fase stationer) kemudian diambil dan dimasukkan kedalam wadah berisi air laut sebanyak 1 L. Rangkaian elektrokoagulasi (Gambar 1) kemudian dipersiapkan dan bagian elektrodanya (anoda dan katoda) selanjutnya dipasang kedalam wadah secara berlawanan. Plat elektroda rangkaian elektrokoagulasi ini terbuat dari plat stainless steel. Percobaan dilakukan dalam jangka waktu 10 menit dengan tegangan konstan masing-masing perlakuan yaitu 5, 10, dan 15 volt. Setelah mencapai waktu yang ditentukan proses ini dihentikan. Sebelum sampel diambil, mikroalga didiamkan selama 5 menit untuk memastikan mikroalga terpisah dan terkonsentrasi secara sempurna dengan cara mengendap atau mengapung ke permukaan. Selanjutnya sampel diambil menggunakan plankton net dan ditiriskan selama 15 menit, kemudian dilakukan uji keefektivitasan pemanenan (rendemen), kualitas air, kadar besi $(\mathrm{Fe})$, dan proksimat.

\section{Kualitas Air}

Pengamatan kualitas air meliputi $\mathrm{pH}$, suhu, dan kadar besi (Fe). Pengecekan $\mathrm{pH}$ dan suhu dilakukan menggunakan multitester pada air sebelum dan sesudah pemanenan (Ilhamdy et al. 2017). Kadar besi (Fe) pada air baru diuji setelah pemanenan dilakukan. Pada tahap ini dilakukan dengan cara mempersiapkan $100 \mathrm{ml}$ larutan sampel kemudian dilakukan penambahan $5 \mathrm{ml} \mathrm{HNO}_{3}$ selanjutnya dipanaskan hingga larutan tersebut hampir kering. Setelah hampir kering ditambahkan $50 \mathrm{ml}$ akuades dan di masukan ke dalam labu ukur $100 \mathrm{ml}$ melalui kertas saring dan ditambahkan akuades hingga batas tera labu ukur. Selanjutnya dilakukan pembuatan kurva kalibrasi menggunakan larutan baku $\mathrm{Fe}$ dengan cara memasukkannya ke dalam AAS menggunakan konsentrasi yang berbeda. Pengukuran dilakukan dengan 
panjang gelombang AAS sebesar 248,3 $\mathrm{nm}$ hingga didapatkan persamaan garis regresi. Selanjutnya larutan sampel yang telah dipersiapkan tadi diukur dengan panjang gelombang yang sama dan hasilnya kemudian dihitung berdasarkan persamaan regresi yang telah dibuat menggunakan larutan baku Fe (Siahaan 2019).

\section{Analisis Proksimat}

Analisis proksimat yang digunakan mengacu pada AOAC (2007). $S$. platensis yang dipanen dalam keadaan biomassa basah kemudian dianalisis kadar air, abu, protein, lemak dan karbohidratnya. Kadar air ditentukan menggunakan oven dengan suhu $100^{\circ} \mathrm{C}$. Kadar abu diperoleh dengan cara membakar sampel dalam tanur pada suhu $\left(600^{\circ} \mathrm{C}\right)$ hingga terbentuk abu. Kadar protein kasar ditentukan menggunakan metode Kjeldahl, dan kadar lemak menggunakan soxhlet, serta nilai karbohidrat dihitung menggunakan konsep by difference.

\section{Analisis Data (Steel dan Torrie 1991)}

Pada analisis data dilakukan dengan bantuan komputer program SPSS 22. Rancangan percobaan ada penelitian ini menggunakan rancangan acak lengkap (RAL). Perlakuan sampel menggunakan beda tegangan yaitu 0,5 , 10 , dan 15 volt. Kode perlakuan sampel yaitu F0 (0 volt), F1 (5 volt), F2 (10 volt), dan F3 (15 volt) dengan tiga kali pengulangan. Model rumus rancangan yang digunakan adalah:

$$
\mathrm{Yijk}=\mu+\tau \mathrm{i}+\varepsilon \mathrm{ij}
$$

\section{Keterangan:}

Yijk : nilai pengamatan pada perlakuan ke-i \& ulangan ke-j

$\mu \quad$ : nilai tengah umum

$\tau i \quad$ : pengaruh perlakuan ke-i

cij : galat percobaan pada perlakuan ke-i \& ulangan ke-j.

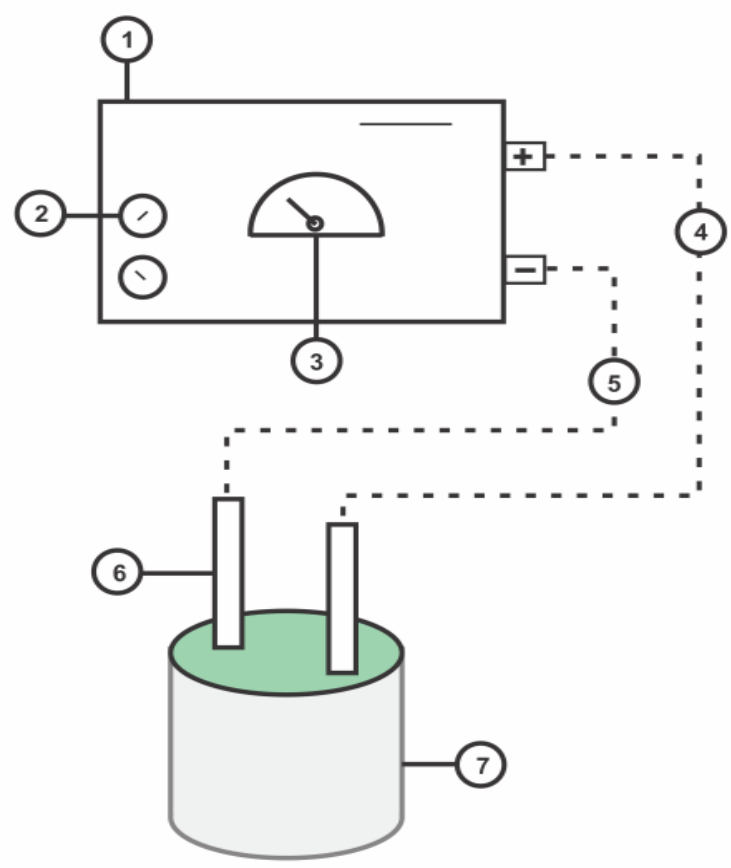

Gambar 1. Rancangan alat elektrokoagulasi (Keterangan: (1) power supply, (2) variabel power supply, (3) voltmeter, (4) katoda (+), (5) anoda (-), (6) plat stainless steel) 


\section{HASIL DAN PEMBAHASAN}

\section{Rendemen S. platensis}

Mikroalga yang dibudidayakan di akuarium dipindahkan ke wadah satu liter, kemudian anoda dan katoda dimasukkan ke dalam wadah dan diberi energi oleh arus searah (DC). Perlakuan F0 dipanen menggunakan jaring plankton, sedangkan untuk perlakuan F1, F2, F3 menggunakan metode elektrokoagulasi dengan tegangan masing-masing $5, \quad 10,15$ volt. Berdasarkan Tabel 1 dapat dilihat bahwa rendemen mikroalga yang dipanen dengan perlakuan F3 memperoleh rendemen tertinggi yaitu 6,05 gr dalam satu liter air budidaya. Penelitian ini menunjukkan bahwa pemanenan $S$. platensis dengan metode elektrokoagulasi 15 volt menghasilkan biomassa lebih banyak dibandingkan dengan plankton net $(\mathrm{F} 0)$.
Menurut Uduman et al. (2011), gumpalan sel mikroalga yang mengapung atau mengendap dikarenakan adanya proses elektrokoagulasi. Hal itu terlihat dari adanya gelembung-gelembung yang ditimbulkan oleh katoda sehingga sel mikroalga menggumpal dan mengapung ke permukaan (Mollah et al. 2001). Jika dua buah elektroda ditempatkan dalam sebuah elektrolit dan dialiri arus listrik searah, maka akan terjadi gejala dekomposisi elektrolit. Peristiwa ini membuat ion negatif tereduksi sehingga berpindah ke anoda dan ion positif (kation) berpindah ke katoda. Pada anoda akan dihasilkan gas berupa gelembung udara dan buih, kemudian gas akan mengikat partikel koloid mikrolga sehingga partikel yang tidak stabil tersebut terdorong ke permukaan (Hakizimana et al. 2017). Proses pemanenan menggunakan elektrokoagulasi dapat dilihat pada Gambar 2.

Tabel 1. Rendemen hasil panen mikroalga S.platensis.

\begin{tabular}{cc}
\hline Perlakuan & Berat sampel (gr) \\
\hline F0 & $3,24 \pm 0,15$ \\
F1 & $1,03 \pm 0,01$ \\
F2 & $2,29 \pm 0,34$ \\
F3 & $6,05 \pm 0,61$ \\
\hline
\end{tabular}

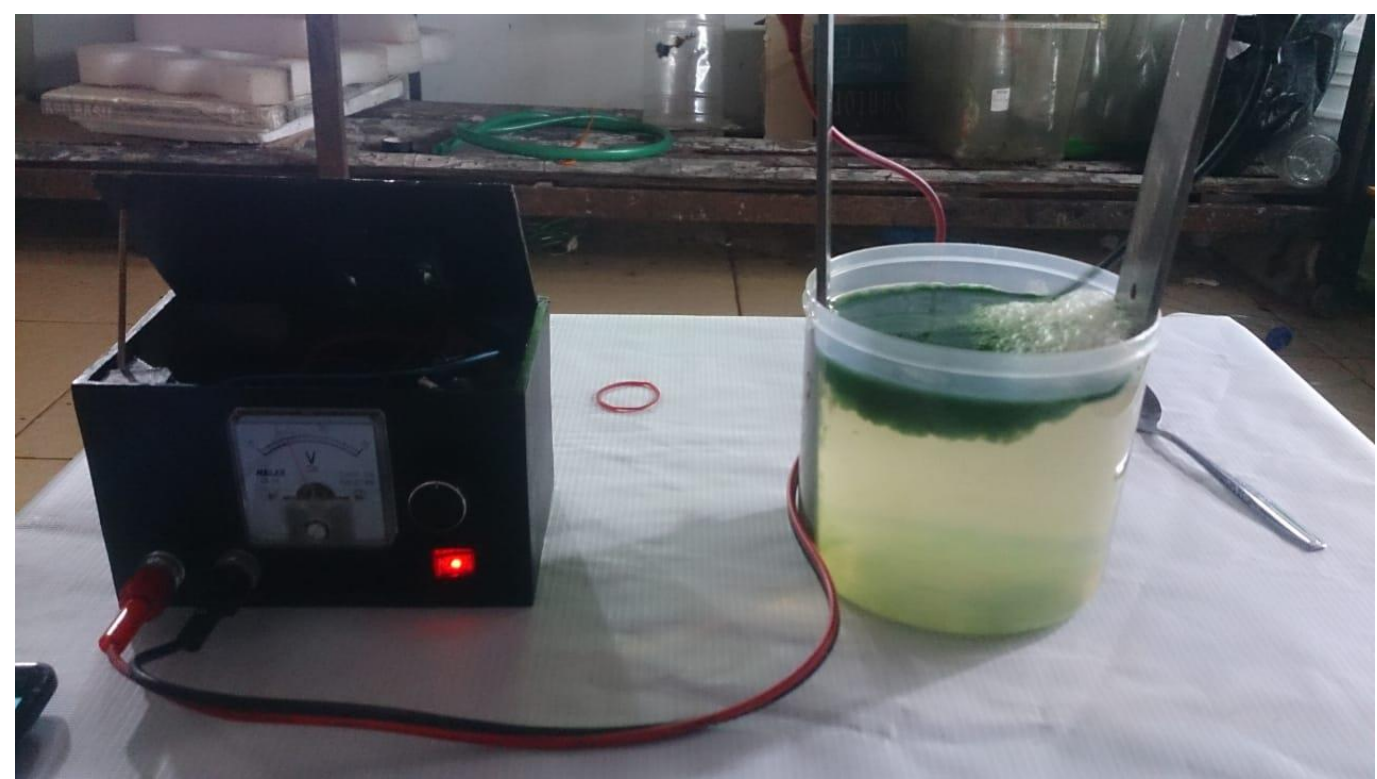

Gambar 2. Proses pemanenan S. platensis menggunakan metode elektrokoagulasi 


\section{Kualitas Air}

Perubahan suhu pada kualitas air yang diamati tidak menunjukkan perubahan yang berarti. Pada perlakuan F0, F1, dan F2 suhunya tidak mengalami perubahan (jumlahnya tetap sebelum dan sesudah panen). $S$. platensis dapat mentolerir suhu pada kisaran $20-40^{\circ} \mathrm{C}$, dan suhu optimum antara $25-35^{\circ} \mathrm{C}$ (Yilmaz 2012). Pada perlakuan F3 terjadi peningkatan suhu sebesar $1^{\circ} \mathrm{C}$ dari $33^{\circ} \mathrm{C}$ menjadi $34^{\circ} \mathrm{C}$. Menurut Uduman et al. (2011), peningkatan biomassa hasil panen mikroalga juga disebabkan oleh sistem konduktivitas listrik yang menyebabkan peningkatan suhu, sehingga tegangan yang besar menyebabkan suhu media meningkat.

Pada parameter $\mathrm{pH} \mathrm{F0,} \mathrm{F1,} \mathrm{dan} \mathrm{F3}$ setelah dan sebelum panen tidak mengalami perubahan yang signifikan (Tabel 2). Akan tetapi, pada perlakuan F2 terjadi perubahan $\mathrm{pH}$ kearah basa pada saat setelah pemanenan. Perubahan tersebut terjadi akibat jumlah ion $\mathrm{OH}^{-}$ yang dihasilkan meningkat. Menurut Ni'am et al. (2007) pemanenan dengan elektrokoagulasi akan mengakibatkan akumulasi $\mathrm{OH}^{-}$sehingga nilai $\mathrm{pH}$ meningkat. Pada warna air yang diamati, menunjukkan adanya perubahan warna setelah pemanenan. Perubahan yang terjadi secara visual dipengaruhi oleh tegangan yaitu semakin tinggi tegangan yang diberikan maka warna yang dihasilkan semakin cokelat (Gambar 3). Hal itu dikarenakan adanya korosi pada plat stainless steel yang digunakan sebagai elektroda (anoda dan katoda) sehingga menyebabkan media berubah warna (Mollah et al. 2001). Proses elektrokoagulasi melepaskan gas hidrogen, yaitu reaksi elektrolisis (reduksi) di katoda, sedangkan pada anoda terjadi reaksi oksidasi (Holt et al. 2002).

Berdasarkan hasil pengujian kadar besi dalam air diketahui bahwa semua kadar besi yang dipanen menggunakan metode elektrokoagulasi hasilnya melebihi ambang batas yang telah ditetapkan oleh Kementerian Kesehatan Republik Indonesia untuk pengolahan air limbah (< 0,3 mg/L) (Koswojo et al. 2010). Beberapa faktor yang menyebabkan tingginya kadar besi adalah korosi pada elektroda pada proses pemanenan. Hal itu senada dengan pernyataan Hakizimana et al. (2017) bahwa proses oksidasi logam atau elektrolit lainnya menyebabkan terjadinya korosi sehingga besi dapat mengalami korosi. Lama waktu pengikisan logam menyesuaikan dengan waktu panen dan tegangan (Ghosh et al. 2007). Hasil tersebut menunjukkan semakin tinggi tegangan yang diberikan maka kadar besinya akan semakin tinggi (Tabel 2).

Tabel 2. Parameter kualitas air setelah pemanenan

\begin{tabular}{lccccc}
\hline \multirow{2}{*}{ Perlakuan } & \multicolumn{2}{c}{$\mathrm{pH}$} & \multicolumn{2}{c}{ Suhu $\left({ }^{\circ} \mathrm{C}\right)$} & \multirow{2}{\text{KadarBesi}}{} \\
\cline { 2 - 5 } & $\begin{array}{c}\text { Sebelum } \\
\text { Panen }\end{array}$ & $\begin{array}{c}\text { Sesudah } \\
\text { Panen }\end{array}$ & $\begin{array}{c}\text { Sebelum } \\
\text { Panen }\end{array}$ & $\begin{array}{c}\text { Sesudah } \\
\text { Panen }\end{array}$ & $(\mathrm{Fe})(\mathrm{mg} / \mathrm{L})$ \\
\hline F0 & 7 & 7 & 32 & 32 & $0,10 \pm 0,03$ \\
F1 & 7 & 7 & 32 & 32 & $8,01 \pm 5,10$ \\
F2 & 7 & 9 & 32 & 32 & $12,29 \pm 5,18$ \\
F3 & 8 & 8 & 33 & 34 & $12,58 \pm 0,65$ \\
\hline
\end{tabular}




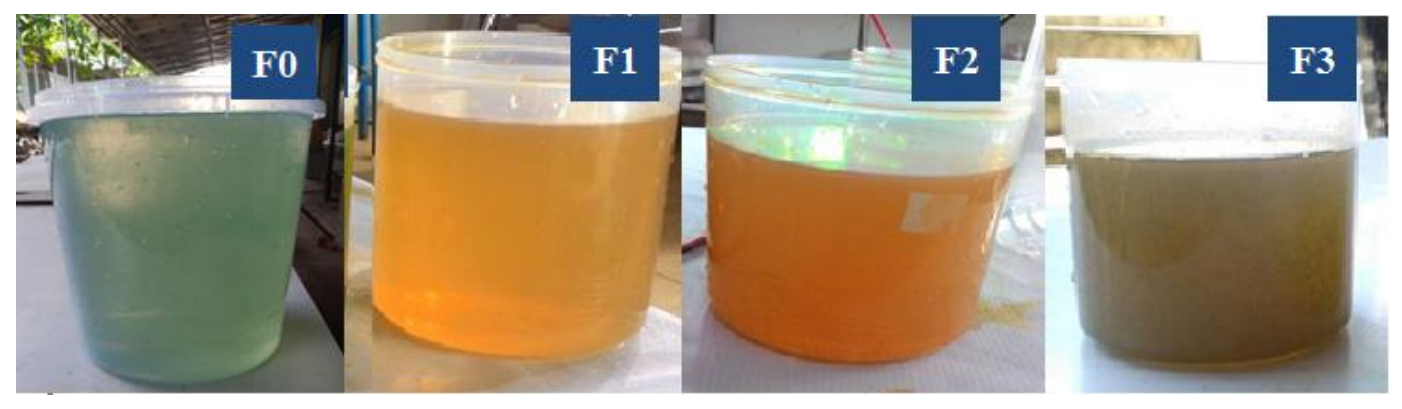

Gambar 3. Warna air setelah pemanenan

\section{Komposisi Proksimat}

Kadar air pada semua perlakuan dengan metode elektrokoagulasi lebih rendah dibandingkan dengan yang dipanen menggunakan plankton net (Tabel 3). Hal tersebut dikarenakan proses pemanenan dengan menggunakan elektrokoagulasi sangat efisien dalam mengeluarkan air (dewatering) (Ghernaout 2019). Proses elektrokoagulasi memiliki keuntungan menghilangkan partikel koloid terkecil karena medan listrik yang diterapkan dapat menetralkan muatan sisa, sehingga memudahkan koagulasi (Al-Shannag et al. 2013). Pada perlakuan F3 nilai kadar abu (34,99 \%) sangat tinggi; Hal ini disebabkan oleh proses elektrokoagulasi menggunakan tegangan tinggi. Nilai tersebut dipengaruhi oleh korosi pelat stainless steel selama proses pemanenan dan kenaikan temperatur yang akan mempercepat terjadinya korosi (Uduman et al. 2011). Hal itu terlihat dari suhu pada perlakuan F3 yang mengalami peningkatan sebesar $\quad 1^{\circ} \mathrm{C}$ setelah pemanenan.

Kadar protein dengan pemanenan elektrokoagulasi lebih rendah dibandingkan dengan pemanenan dengan plankton net. Hal ini dikarenakan adanya proses denaturasi protein karena semakin tinggi tegangan maka semakin rendah kandungan proteinnya. Menurut Ishiwatari et al. (2013), denaturasi protein dapat terjadi karena beberapa faktor, seperti perubahan garam, perubahan $\mathrm{pH}$ yang drastis, dan logam berat. Pada proses elektrokoagulasi, garam berubah sesuai dengan nilai tegangan sehingga proses denaturasi protein akan terjadi seiring dengan tingginya tegangan yang diberikan (Hakizimana et al. 2017).

Nilai kadar lemak mengikuti pola yang terjadi pada protein, hal ini disebabkan oleh adanya oksidasi lemak sehingga kadarnya menjadi menurun seiring meningkatnya tegangan yang diberikan. Menurut Ghernaout (2019) polimer-polimer yang mengandung rantai panjang dapat teroksidasi seiring dengan penambahan tegangan yang diberikan. Selain itu, S. platensis juga merupakan mikroalga dengan kandungan lemak rendah $0,1-7 \%$. Sebanyak $25-60 \%$ dari total lemak merupakan asam lemak tak jenuh yang memiliki ikatan rangkap sehingga mudah untuk teroksidasi (Spolaore et al. 2006). Kandungan karbohidrat pada semua perlakuan berbeda nyata. Nilai terkecil ditemukan pada perlakuan F0 dan tertinggi pada perlakuan F2. Nilai tersebut dipengaruhi oleh adanya proses koagulasi terhadap karbohidrat yang terkandung di dalam mikroalga (Uduman et al. 2011). Selain itu, karbohidrat juga nilainya dipengaruhi oleh kadar air karena perhitungannya dilakukan secara by difference (Yilmaz 2012). 
Tabel 3. Komposisi proksimat Spirulina platensis

\begin{tabular}{lrrrr}
\hline \multirow{2}{*}{ Parameter } & \multicolumn{4}{c}{ Perlakuan } \\
\cline { 2 - 5 } & \multicolumn{1}{c}{ F0 } & F1 & F2 & F3 \\
\hline Kadar air (\%) & $24,58 \pm 0,12^{\mathrm{d}}$ & $12,32 \pm 0,10^{\mathrm{a}}$ & $15,36 \pm 0,23^{\mathrm{b}}$ & $17,48 \pm 0,06^{\mathrm{c}}$ \\
Kadar abu (\%) & $22,42 \pm 0,06^{\mathrm{a}}$ & $26,56 \pm 0,16^{\mathrm{b}}$ & $26,53 \pm 0,24^{\mathrm{b}}$ & $34,99 \pm 0,11^{\mathrm{c}}$ \\
Kadar lemak (\%) $^{\text {Kadar protein (\%) }}$ & $1,65 \pm 0,01^{\mathrm{d}}$ & $1,27 \pm 0,03^{\mathrm{c}}$ & $0,86 \pm 0,06^{\mathrm{b}}$ & $0,65 \pm 0,06^{\mathrm{a}}$ \\
Kadar karbohidrat (\%) $^{\mathrm{a}}$ & $17,24 \pm 0,00^{\mathrm{d}}$ & $30,26 \pm 0,00^{\mathrm{c}}$ & $25,81 \pm 0,14^{\mathrm{b}}$ & $21,67 \pm 0,13^{\mathrm{a}}$ \\
\hline
\end{tabular}

Ket: huruf superscript yang berbeda menunjukkan adanya beda nyata pada tingkat $\alpha: 0,05$

\section{KESIMPULAN}

Pemanenan Spirulina platensis menggunakan metode elektrokoagulasi dengan tegangan 15 volt menghasilkan lebih banyak biomassa bila dibandingkan dengan menggunakan plankton net. Namun, kandungan proksimat yang dihasilkan menggunakan metode elektrokoagulasi lebih rendah.

\section{UCAPAN TERIMA KASIH}

Peneliti mengucapkan terima kasih banyak kepada Kementerian Riset, Teknologi dan Perguruan Tinggi atas pemberian dana hibah "Penelitian Dosen Pemula".

\section{DAFTAR PUSTAKA}

Addini I, Saputra D, Ilhamdy AF, Julianto T. (2017). Pertumbuhan mikroalga Spirulina platensis yang dikultur dengan media teknis. Jurnal Intek Akuakultur. 1(1): 5152.

Al-Shannag M, Bani-Melhem K, AlAnber Z, Al-Qodah Z. (2013). Enhancement of COD-nutrients removals and filterability of secondary clarifier municipal wastewater influent using electrocoagulation technique. Separation Science and Technology. 48(4): 673-680. https://doi.org/10.1080/01496395.2 012.707729 .

Ambrozova JV, Misurcova L, Vicha R, Machu L, Samek D, Baron M, Micek J, Sochor J, Jurikova T. (2014). Influence of extractive solvents on lipid and fatty acids content of edible freshwater algal and seaweed products, the green microalga Chlorella kessleri and the cyanobacterium Spirulina platensis. Molecules. 19(2): 2344-2360. https://doi.org/10.3390/molecules19 022344.

[AOAC] Association of Official Analytical Chemist. (2007). Official of Analysis of the Association of Official Analytical of Chemist. Mayland (USA). The Association of Official Analytical of Chemist, Inc.

Barros AI, Gonçalves AL, Simões M, Pires JC. (2015). Harvesting techniques applied to microalgae: A review. Renewable and Sustainable Energy Reviews. 41: 1489-1500. https://doi.org/10.1016/j.rser.2014.0 9.037 .

Chen CY, Yeh KL, Aisyah R, Lee DJ, Chang JS. (2011). Cultivation, photobioreactor design and harvesting of microalgae for biodiesel production: A critical review. Bioresource Technology. 102: $\quad$ 71-81. https://doi.org/10.1016/j.biortech.20 10.06.159.

Gami B, Naik A, Patel B. (2011). Cultivation of Spirulina species in different liquid media. Journal of Algal Biomass Utilization. 2(3):1526.

Ghernaout D. (2019). Electrocoagulation 
process for microalgal biotechnology: A review. Applied Engineering. 3(2): 85-94. https://doi.org/10.11648/j.ae.20190 302.12 .

Ghosh D, Solanki H, Purkait MK. (2008). Removal of Fe (II) from tap water by electrocoagulation technique. Journal of Hazardous Materials. $\quad 155(1)$ : 135-143. https://doi.org/10.1016/j.jhazmat.20 07.11.042.

Grima EM, Belarbi EH, Acien FG, Medina AR, Chisti Y. (2003). Recovery of microalgal biomass and metabolites: process options and economics. Biotechnology Advances. 20: 491-515. https://doi.org/10.1016/S07349750(02)00050-2.

Hadiyanto H, Hendroko R. (2014). Integrated biogas-microalgae from waste waters as the potential biorefinery sources in Indonesia. Energy Procedia. 47: 143-148. https://doi.org/10.1016/j.egypro.201 4.01.207.

Hakizimana JN, Gourich B, Chafi M, Stiriba Y, Vial C, Drogui P, Naja J. (2017). Electrocoagulation process in water treatment: A review of electrocoagulation modeling approaches. Desalination. 404: 121.

https://doi.org/10.1016/j.desal.2016. 10.011 .

Holt PK, Barton GW, Wark M, Mitchell CA. (2002). A quantitative comparison between chemical dosing and electrocoagulation. Colloids and Surfaces A: Physicochemical and Engineering Aspects. 211: 233-248. https://doi.org/10.1016/S09277757(02)00285-6.

Ilhamdy AF, Nurhayati T, Setyaningsih I, Santosa DA. (2017). Optimization process of ethanol production from microalgae Chlamydomonas sp. ICBB 9113, ICBB 9114, and Synechococcus sp. ICBB 9111. Asian Journal of Environmental Biotechnology. 1: 10-18.

Ishiwatari N, Mkia F, Noboru S. (2013). Effect protein denaturation degree on texture and water state of cooked meat. Journal of Food Engineering. 117: 361-369. https://doi.org/10.1016/j.jfoodeng.2 013.03.013.

Koswojo R, Utomo RP, Ju YH, Ayucitra A, Soetaredjo FE, Sunarso J, Ismadji S. (2010). Acid green 25 removal from wastewater by organo-bentonite from Pacitan. Applied Clay Science. 48(1): 81-86. https://doi.org/10.1016/j.clay.2009. 11.023 .

Milledge JJ, Heaven S. (2013). A review of the harvesting of micro-algae for biofuel production. Reviews in Environmental Science and BioTechnology. 12(2): 165-178. https://doi.org/10.1007/s11157-0129301-z.

Mollah MYA, Schennach R, Parga JR, Cocke DL. (2001). Electrocoagulation (EC): Science and applications. Journal of Hazardous Materials. 84(1): 29-41. https://doi.org/10.1016/S03043894(01)00176-5.

Ni'am M, Othman F, Sohaili J, Fauzia Z. (2007). Removal of COD and turbidity to improve wastewater quality using electrocoagulation technique. The Malaysian Journal of Analytical Science. 11(1): 198205.

Pohl P, Ohlhase MK, Rautwurst SK, Baasch KLK. (1987). An inexpensive inorganic medium for the mass cultivation of freshwater microalgae. Phytochemistry. 
26(6):1657-1659.

https://doi.org/10.1016/S0031-

9422(00)82264-5.

Promya J, Traichaiyaporn S, Deming R. (2008). Phytoremediation of kitchen wastewater by Spirulina platensis (Nordstedt) Geiteler : pigment content, production variable cost and nutritional value. Maejo International Journal of Science and Technology. 20(1): 159-171.

Puspanadan S, Wong XJ, Lee CK. (2018). Optimization of freshwater microalgae, Arthrospira sp. (Spirulina) for high starch production. International Food Research Journal. 25(3): 12661272.

Samek D, Mišurcová L, Machù L, Buòka F, Fišera M. (2013). Influencing of amino acid composition of green freshwater algae and cyanobacterium by methods of cultivation. Turkish Journal of Biochemistry. 38(4): 360-368. https://doi.org/10.5505/tjb.2013.421 04.

Siahaan MA. (2019). Analisis kadar besi (Fe) pada air sumur gali penduduk wilayah Komplek Rahayu, Kelurahan Mabar Hilir, Kecamatan Medan Deli, Kota Medan. Jurnal Kimia Saintek dan Pendidikan. 3(1): 19-22.

Sim TS, Goh A, Becker EW. (1988). Comparison of centrifugation, dissolved air flotation and drum filtration technique for harvesting sewage-grown algae. Biomass. 16: 51-62.

https://doi.org/10.1016/01444565(88)90015-7.

Singh G, Patidar SK. (2018). Microalgae harvesting techniques: A review. Journal of Environmental Management. 217: 499-508. https://doi.org/10.1016/j.jenvman.2
018.04.010.

Soni RA, Sudhakar K, Rana RS. (2017). Spirulina-From growth to nutritional product: A review. Trends In Food Science \& Technology. 69: 157-171. https://doi.org/10.1016/j.tifs.2017.0 9.010 .

Spolaore P, Cassan CJ, Duran E, Isambert A. (2006). Commercial applications of microalgae. Journal of Bioscience and Bioengineering. 101(2): $\quad$ 87-96. https://doi.org/10.1263/jbb.101.87.

Steel RGD, Torrie JH. (1991). Prinsip dan Prosedur Statistika Suatu Pendekatan Biometrik. Jakarta: PT Gramedia Pustaka Utama.

Uduman N, Bourniquel V, Danquah MK, Hoadley AFA. 2011. A parametric study of electrocoagulation as a recovery process of marine microalgae for biodiesel production. Chemical Engineering Journal. 174: 249-257. https://doi.org/10.1016/j.cej.2011.0 9.012 .

Yilmaz HK. (2012). The proximate composition and growth of Spirulina platensis biomass (Arthrospira platensis) at different temperatures. Journal of Animal and Veterinary Advances. 11(8): 1135-1138.

https://doi.org/10.3923/javaa.2012.1 135.1138 .

Zhu C, Zhai X, Jia j, Wang J, Han D, Li Y, Tang Y, Chi Z. (2018). Seawater desalination concentrate for cultivation of Dunaliella salina with floating photobioreactor to produce $\quad \beta$-carotene. Algal Research. 35: 319-324. https://doi.org/10.1016/j.algal.2018. 08.035 . 